International Journal of Instruction e-ISSN: 1308-1470 • www.e-iji.net



October $2019 \bullet$ Vol.12, No.4

p-ISSN: 1694-609X

pp. 281-296

Received: 08/12/2018

Revision: 01/06/2019

Accepted: 06/06/2019

OnlineFirst:15/08/2019

\title{
Input Flooding, Input Enhancement and Writing Performance: Effects and Percepts
}

\section{Maryam Safdari}

MA Graduate in TEFL Islamic Azad University at Central Tehran Branch, Faculty of Foreign Languages, English Department, Tehran, Iran, safdari.maryam@yahoo.com

Most research studies show the focus of EFL courses in the Iranian educational context is on speaking in private language schools and on grammar, reading and vocabulary in state schools. Consequently, more research regarding writing is required in the Iranian EFL context. The present study sets out to investigate the effects of input enhancement and input flooding of the present simple and continuous tenses on Iranian EFL learners' writing. Moreover, the study examined learners' perceptions of the efficacy of the two input types for improving writing. The participants were $60 \mathrm{EFL}$ learners in three groups of 20. In experimental group one, present simple and continuous tenses in texts were enhanced via underlining, boldfacing, italicization, capitalization, colour coding and using different font sizes. In experimental group two, learners received flooded materials via increasing the frequency of tenses. The control group was exposed to the same texts; however, the texts were neither enhanced nor flooded. After the treatment, the three groups received the writing posttest. To explore learners' perceptions towards the efficacy of input types for improving their writing, five participants in each experimental group were interviewed. The results indicated that both input enhancement and input flooding positively affected learners' writing.

Keywords: input flooding, input enhancement, grammar, writing performance, English as a Foreign Language (EFL)

\section{INTRODUCTION}

A review of the literature shows that writing is an important skill in most educational contexts in general and in ELT contexts in particular. Given that writing has an essential role in L2 learning and teaching, it has been the focus of many recent studies (e.g., Alipanahi, 2015; Lai, 2015; Ketabi \& Torabi, 2013; Khodabakhshzadeh \& Samadi, 2018; McCutchen, 2011; Wigglesworth \& Storch, 2009). According to Melissourgoua and Frantzi (2015), English writing and correspondence play a very important cultural role in various commercial activities, organizations, and governmental initiatives worldwide. In fact, writing has come to be considered as an essential component of education, characterized as an important path in L2 learning. In general, having the

Citation: Safdari, M. (2019). Input Flooding, Input Enhancement and Writing Performance: Effects and Percepts. International Journal of Instruction, 12(4), 281-296. https://doi.org/10.29333/iji.2019.12418a 
ability to write effectively can be interpreted as proof of mastery over the L2 (Lai, 2005). Actually, writing is viewed as a basic communication skill as well as a unique asset during the process of learning an L2 (Al-Meni, 2008). Dekeyser and Sokalski (1996) noted that despite the fact that it is easy to learn some grammatical forms, it is difficult to employ them in productive skills.

Writing, in general, and second language writing, in particular, brings about multiple challenges to people (McCutchen, 2011). Clearly, some individuals are very good at speaking a second language but the same individuals have very poor performance when it comes to writing a letter or a cover letter. Raising the same challenges, Jun (2008) notes that writing in an L2 poses many challenges to second language learners and hence a complex topic for researchers examining second language acquisition. As one of the main components of language in general and writing in particular, learning grammar can be very challenging to the students (Widodo, 2004). Being equipped with adequate grammar knowledge, one can perform productive skills effectively. Moreover, any grammatical mistakes can lead to misunderstanding in all language aspects (Zhong-guo \& Min-yan, 2007). It follows that grammar serves as a basis for all language skills. Regarding productive skills, especially writing, grammar plays a very significant role (Swan, 2009). Swan (2009) characterizes grammar as a system of rules, which shows how words are organized, arranged or modified to impart the intended meaning.

In the view of Thornbury (2004), the notion of grammar is described as a set of rules indicating how language is used. In fact, these rules are employed to string the words together, enabling L2 learners to engage in meaningful, accurate communication. They also enhance the L2 learners' communicative skills. Grammar teaching, particularly its contribution to L2 acquisition has been the focus of controversy. As discussed by Thornbury (1999), no other concern has caught the attention of theorists and practitioners more than grammar. A look at the history of L2 teaching reveals that L2 teaching is mainly the history of claims and counter claims made by the pros and cons of grammar teaching.

Thus, grammar has been the subject of many investigations both at the local Iranian ELT context (e.g., Aslani, \& Heidari Tabrizi, 2015; Azizifar, Babaei, Jamalinesari, \& Gowhary, 2015; Ghafoori, Dastgoshadeh, Aminpanah, \& Ziaei, 2016; Mahjoob, 2015; Zarifi, \& Taghavi, 2016) as well as the international context of ELT (e.g., Shahzadi, \& Janjua, 2016; Tarasova, Mukhar lyamova, Ashrapova, Mukhamet zyanova, Shayak hmetova, \& Ilyasova, 2016; Underwood, 2017; Vujic, 2015; Widianingsih, \& Gulö, 2016). A look at the history of language teaching indicates that similar to grammar input has almost always had a central position. As VanPatten (2004) notes there is a general agreement among researchers that input plays a pivotal role in SLA and its significance cannot be overlooked. Input refers to the language that a learner hears or sees in order to comprehend the message (VanPatten, 2004).

Many studies have attached enormous importance to the role of input in language acquisition. For example, Ellis (1990) as an advocate of Universal Grammar asserted that input (known as positive evidence) should be provided to the L2 learners so that they can activate UG devices in order to learn UG parameters and hence, learning an L2. 
Likewise, Anderson $(1982,1983)$ emphasized the significant role of input in developing different language skills and components. However, just exposing learners to input does not guarantee language acquisition message (VanPatten, 2004).

Similarly, as pointed out by Lightbrown and Spada (1990), L2 learners may not be able to perceive specific structures in naturalistic input even after being exposed to the structures for a long time. Put it another way, the input does not turn into intake if L2 learners are left on their own resources (Widdowson, 1990). Thus texts should be manipulated at times to draw learners' attention and assist them in transforming input to intake and being able to produce the forms under instruction meaningfully and correctly (Ellis, 1997).

As Schmidt (2001) maintains, failure to process linguistic forms and meaning and more importantly the inability to notice the features of input are the reasons why teachers need to use input enhancement techniques. As Schmidt (2001) says, noticing the language forms certainly results in the more effective acquisition of L2 forms. In the same vein, second language learning requires L2 learners to turn their attention to different language forms and components. In accordance with Noticing Hypothesis, drawing the learners' attention to L2 input provides an important and adequate condition for changing input into intake for learning to occur (Schmidt, 2001). There are many ways to manipulate and enhance the text, one of which is making certain items in input prominent by typographically manipulating them. In fact, the learner would fail to notice the same input without such enhancements (Simard, 2002). This is referred to as input enhancement.

Initially put forth by Smith (1993), input enhancement allows learners to concentrate on important features including the grammatical features of a text. This is likely to improve their writing skill. Input enhancement is mainly aimed at improving the consciousness of learners regarding various features and components of the language. Actually, input enhancement is considered as a typographical means to make forms prominent in written texts (e.g., underlining, using different fonts and colors of print, etc.) for purposes of focusing the learners' attention on a particular linguistic form (Simard, 2002; Smith, 1993).

Another way to manipulate input is input flooding. Nation (1990) defines input flooding as the exposure of learners to numerous instances of a structure in a written text. As Wong (2004) notes input flooding facilitates the provision of comprehensible input since learners are exposed to frequently to the target form and the chances of noticing increase (Wong, 2004).

Multiple investigations have been conducted to examine the effect of input flooding and input enhancement on different language skills and features. Fahim and Vaezi (2011) studied the extent to which visual/textual input-based enhancement would result in the improvement of learning collocations. The findings indicated that the enhanced input could make a significant contribution to the acquisition of the items.

Mayen (2013) investigated the impact of visual prompts as an input enhancement technique on L2 learners in terms of learning verbal morphology. Their study showed that the use of visual aids as an example of input enhancement technique provided the 
second language learners with opportunities to notice and remember the verbal morphology.

A study carried out by Afraz and Ebrahimi (2014) was aimed at exploring the impact of input enhancement as well as input flooding on learning causative structures among Iranian EFL learners. The results showed that input enhancement and input flooding influenced learning causative structures positively. However, the findings showed no significant difference between the impact of either of input enhancement and input flooding on their performance on the causative structure test.

Nemati and Motallebzadeh (2013) conducted an investigation to examine the effect of implicit focus on form mediated by input flooding on structural accuracy. The findings revealed no significant effect of the instructional treatment, i.e. input flooding, on learning the target forms.

Asadi, Amirabadi, Biria and Sedaghat (2014) sought to shed light on the extent to which input enhancement, input flood, as well as the combination of these two types of text manipulation can influence Iranian EFL learners' recall of conditional structures. The results showed that those participants who received a combination of input flood and input enhancement had better performance than others in the other two classes.

Birjandi, Alavi and Najafi (2015) conducted a study to explore the potential impact of unenhanced, enhanced, and elaborated input on learning English phrasal verbs among L2 Learners. The findings showed that typographical input enhancement was more helpful than the unenhanced and elaborated input in terms of their effects on learning English phrasal verbs than.

Tahmouresi, Ahmadi and Gholami (2015) tried to shed light on whether textual input enhancement can improve the acquisition of English verbals among Iranian High school learners. The findings showed that the participants in the experimental group who had been exposed to input enhancement outperformed those in the control group. The results also showed that textual input enhancement improved EFL learner's acquisition of verbal.

In a study, Baghban Ferdous (2015) examined the impact of written output and input enhancement on EFL learners' grammatical development. The findings indicated that two classes who were exposed to written output and input enhancement were found to be insignificantly different with respect to learning L2 forms in the recognition test. But, the findings pointed to the more effective performance of the output group compared to the non-output group on the production test.

Loewen and Inceoglu (2016) conducted an investigation to find out the effectiveness of visual input enhancement on noticing and developing the Spanish past tense. The findings showed the learners' knowledge of the highlighted grammatical forms provided in the text; however, no difference was found in the extent of attention allocated to the forms by the groups exposed to the enhanced and unenhanced texts. Furthermore, those participants in both groups who had received the enhanced and unenhanced input improved their knowledge of the L2 forms. No significant difference was found in the improvement of the two groups. 
As the review of literature reveals, input has a critical role in language acquisition. Additionally, different types of input may impact learning different language skills and components differently. Flooded input has the potential to increase the amount of exposure that learners receive while enhanced input can attract the learners' attention. Both of these input types can ultimately lead to more noticing and noticing can culminate in better learning. Furthermore, in the Iranian EFL context, most classroom activities are focused on speaking in private language schools. As for state schools, classroom activities are mainly focused on grammar, vocabulary and reading. In both of these settings, in the Iranian content of ELT, not adequate attention is devoted to writing. Therefore, more research into what types of materials can possibly contribute to writing is essential. Moreover, as the review of the previous studies indicates to date, and to the researcher's best knowledge, no study has so far been attempted to investigate the effects of input flooding and input enhancement of present simple and continuous tenses on the writing performance of Iranian EFL learners, which will be the focus of the current study. The findings of the current study are of significance as they can provide a more comprehensive picture of how different input types can affect EFL learners' writing performance. To meet the objectives of this study, the following research questions were formulated:

RQ1: Does input enhancement of present simple and continuous tenses significantly improve Iranian elementary EFL learners' writing performance?

RQ2: Does input flooding of present simple and continuous tenses significantly improve Iranian elementary EFL learners' writing performance?

RQ3: Is there any statistically significant difference between the effects of input flooding and input enhancement of present simple and continuous tenses on Iranian elementary EFL learners' writing performance?

RQ4: What are the perceptions of Iranian elementary EFL learners towards the efficacy of input enhancement and input flooding towards the improvement of writing performance?

\section{METHOD \\ Participants}

The participants of the present study were sampled from elementary EFL learners studying English in a language school in Tehran, Iran. As the teacher-researcher was not able to randomly sample the learners, she resorted to intact classes and in total six such classes participated in the study, with two classes being assigned to experimental group one receiving enhanced materials, two classes being assigned to experimental group two receiving flooded materials and two classes being assigned to control group receiving the conventional materials which were neither enhanced nor flooded.

After the intact classes were selected, the researcher randomly assigned them to the three groups. The whole selected sample included seventy-five EFL learners. Subsequent to the administration of a proficiency test, those learners whose scores were within one standard deviation above and below the mean score were selected as the eligible participants of the study. Finally, in total each group comprised of twenty 
learners. The participants were all female learners within the age range of 18 to 25 , as the researcher did not have access to male learners and other age groups.

\section{Instruments and Materials}

To carry out the present study, the researcher made use of the following instruments and materials:

\section{Key English Test (KET)}

KET includes three papers with paper one containing reading and writing. This paper consists of five parts, which has $\% 50$ of the final marks. Paper two is devoted to listening and contains five parts carrying \%25 of final marks. The third paper includes the speaking part with a total number of 25 , which takes $\% 25$ of the total mark. Cambridge Key English Test (KET) was used in the current study to make sure that the selected participants of the study were homogeneous in terms of overall language proficiency as well as writing performance prior to the treatment. To this aim, KET was initially piloted on 30 participants having similar characteristics to the main participants of the study and Cronbach's alpha was run on the scores. The Cronbach's Alpha index turned out to be .78 which is considered satisfactory. Moreover, to make sure that the writing scores for the pretest and posttest were reliable, inter-rater reliability was calculated after two raters (the researcher and an experienced EFL teacher with an MA degree in applied linguistics) scored the writing pretest and posttest papers. The reliability indices computed were .87 and .82 for the writing pretest and posttest, respectively.

\section{Writing Pretest and Posttest}

The writing scores of KET given to the learners for homogeneity purposes were used as the pretest writing scores. The writing paper of another sample KET was used as the posttest and administered to the three groups at the end of the course.

\section{Rating Scale for the KET Writing Part}

For the assessment of KET writing section, the researcher used the KET general mark scheme, which is used as a rubric for a summative score. According to the KET rating scale, the criteria include language range, variety, complexity, message communication, grammatical structure, vocabulary, spelling, punctuation, content points, length, and target reader. The maximum overall score would be 15 .

\section{Semi-Structured Interviews}

A set of semi-structured interview questions were prepared regarding the participants' attitudes towards the efficacy of input enhancement and input flooding towards improving their writing. To report the results of the interviews, the content analysis approach recommended by Auerback and Silverstein (2003) was used.

As Auerback and Silverstein (2003) maintain, content analysis is the most common form of analysis when dealing with qualitative data. They further enumerate six stages which the analyzer needs to go through to come up with established and meaningful patterns. These phases are namely: getting familiar with data, coming up with initial codes, looking for themes among codes, reviewing the themes, defining and labelling the 
themes, and producing the final report. The six stages proposed above were taken into consideration to report the interview contents.

\section{Materials}

Five texts were downloaded from the internet and modified in line with Norris and Ortega (2000) for input enhancement and Nemati, and Motallebzadeh (2013) for input flooding. To make sure that the texts were at the right level, the researcher calculated their readability. To this aim, a readability scale provided by a free online tool called Textalyser (http://textalyser.net/) was used to compute the readability index of the reading material. The use of Textalyser to estimate readability in this study was followed in line with Gunning (1652 as cited in Kol \& Schcolnik, 2008). According to Kol and Schcolnik (2008) Gunning maintains that a readability index of around 11 or 12 is considered very difficult and the desirable readability index falls between 4 to 6 . All the five texts used in the present study had readability between 4 to 4.5 . The texts comprised around 150 words each. For the input enchantment group, the present simple and continuous tenses in the texts were enhanced through highlighting, boldfacing, italicizing, changing the font type, italicizing and coloring. For the input flooding group, the frequency of the present simple and continuous tenses in the texts were raised.

\section{Procedure}

Initially, KET was piloted on 30 participants to assure that it was reliable for the present research context. Next, KET was given to 75 learners at the elementary level and based on the mean and standard deviation, 60 learners were selected. These participants were divided into two experimental and a control group each consisting of 20 learners. The participants stayed in their intact classes throughout the treatment. Then the writing scores of the KET belonging to the 60 learners were analyzed using a One-way analysis of Variance (ANOVA) to make sure that the three groups were not statistically different in terms of writing performance prior to the treatment. After making sure that the three groups of the study were homogeneous in terms of overall language proficiency and writing performance the treatment started.

In experimental group one, the present simple and continuous tenses used in the selected texts were enhanced in line with Norris and Ortega's (2000) to make input enhanced. The techniques applied included underlining, boldfacing, italicization, capitalization, color coding and using various font sizes or types. To this aim, the researcher retyped the materials and modified them. In the second experimental group, the participants were flooded with the present simple and continuous tenses in the texts drawing on Nemati and Motallebzadeh's (2013) guidelines for input flooding. As Nemati and Motallebzadeh (2013) note input flooding refers to increasing the frequency of appearance of a given feature in the input, thus making such feature more prominent. Similarly, in the present study, the learners in the second experimental group were exposed to the present simple and continuous tenses several times in the texts. As noted earlier, the texts and topics were exactly the same ones as in experimental group one. The control group participants were also exposed to the same texts; however, their texts were neither enhanced nor flooded. At the end of the treatment, the participants in the 
three groups received the posttest of writing and the scores were analyzed to address the research questions. Moreover, to explore the perceptions of the participants towards the efficacy of input enhancement and input flooding towards the improvement of their writing performance, five participants in each experimental group were interviewed.

\section{FINDINGS}

\section{Analysis of Writing Pretest Scores}

To make sure that the three groups of the study were not statistically different in terms of writing performance, a One-way ANOVA was run on the pretest writing scores. Table 1 displays descriptive statistics of writing pretest scores.

Table 1

Descriptive Statistics of Writing Pretest Scores

\begin{tabular}{lllllll}
\hline & $\mathrm{N}$ & Mean & Std. Deviation & Std. Error & Minimum & Maximum \\
\hline Flood & 20 & 11.9000 & 2.86 & .41612 & 7.00 & 13.00 \\
Enhanced & 20 & 11.8500 & 2.42 & .66112 & 8.00 & 12.00 \\
Control & 20 & 11.5500 & 2.16 & .48382 & 6.00 & 12.00 \\
\hline
\end{tabular}

Before running One-way ANOVA, it should be mentioned that the assumption of homogeneity of variances was met (Levene's F $(2,57)=2.312, P>.05)$ (Table 2).

Table 2

Levene's Test of Equality of Error Variances for the Pretest Scores

\begin{tabular}{llll}
\hline $\mathrm{F}$ & $\mathrm{df} 1$ & $\mathrm{df} 2$ & Sig. \\
\hline 2.312 & 2 & 57 & .214 \\
\hline
\end{tabular}

Table 3 displays the results of One-way ANOVA run on the pretest writing scores of the three groups to assure that the three groups were not statistically different in terms of writing prior to the treatment.

Table 3

Results of ANOVA on Writing Pretest Scores

\begin{tabular}{llllll}
\hline & Sum of Squares & df & Mean Square & F & Sig. \\
\hline Between Groups & 1.233 & 2 & .717 & .321 & .410 \\
Within Groups & 230.950 & 57 & 5.052 & & \\
Total & 232.183 & 59 & & & \\
\hline
\end{tabular}

Results of ANOVA (Table 3) indicated that the groups were not significantly different in terms of writing pretest scores $(\mathrm{F}=0.321, P<0.05)$. Accordingly, it was concluded that participants of the study are homogenized in terms of writing before receiving treatment.

\section{Analysis of Writing Posttest Scores}

To investigate any significant differences between the performances of the three groups in terms of writing performance, the posttest writing scores of the groups were analyzed via running a One-way ANOVA. Table 4 demonstrates the descriptive statistics for the writing posttest scores of the three groups. 
Table 4

Descriptive Statistics of Writing Posttest Scores

\begin{tabular}{lllllll}
\hline & $\mathrm{N}$ & Mean & Std. Deviation & Std. Error & Minimum & Maximum \\
\hline Flood & 20 & 14.5200 & 3.36 & .52421 & 9.00 & 15.00 \\
Enhanced & 20 & 14.2800 & 3.12 & .74512 & 10.00 & 15.00 \\
Control & 20 & 11.8700 & 2.98 & .23143 & 7.00 & 12.00 \\
\hline
\end{tabular}

It should be noted that prior to running One-way ANOVA, the assumption of homogeneity of variances was met (Levene's F $(2,57)=3.421, P>.05)$ (Table 5).

Table 5

Levene's Test of Equality of Error Variances for the Posttest Writing Scores

\begin{tabular}{llll}
\hline $\mathrm{F}$ & $\mathrm{df} 1$ & $\mathrm{df} 2$ & Sig. \\
\hline 3.421 & 2 & 57 & .185 \\
\hline
\end{tabular}

Table 6 illustrates the results of One-way ANOVA run on the posttest writing scores of the three groups to investigate any significant differences between the writing performances of the three groups after treatment.

Table 6

Result of One-way ANOVA on the Writing Posttest Scores

\begin{tabular}{llllll}
\hline & Sum of Squares & df & Mean Square & F & Sig. \\
\hline Between Groups & 332.033 & 2 & 166.017 & 39.404 & .000 \\
Within Groups & 240.150 & 57 & 4.213 & & \\
Total & 572.183 & 59 & & & \\
\hline
\end{tabular}

The results of ANOVA (Table 6) showed that significant differences existed between the three groups of the study $(\mathrm{F}=39.40, P<0.05)$. Based on this result, it can be concluded that somewhere between the groups' significant differences existed which means that at least one of the groups outperformed the other two or one of them. To determine where exactly difference(s) lay between the groups, the post hoc test of Tukey was run. Table 7 presents the results of multiple contrasts by employing the post hoc test of Tukey for the writing posttest scores.

Table 7

Result of Multiple Comparisons by Tukey Test

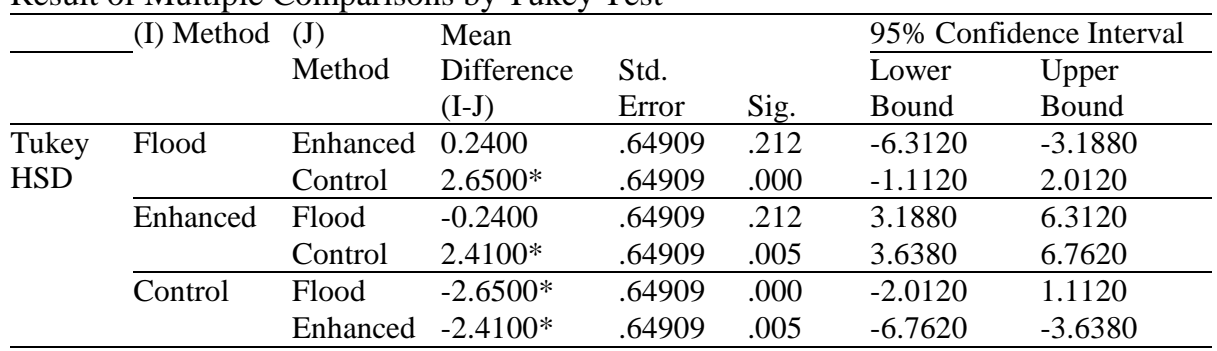

*. The mean difference is significant at the 0.05 level.

According to the output of multiple contrasts, the input enhancement group outperformed the control group $(p=.005<0.05)$. Likewise, the input flood group 
outperformed the control group $(p=.000<0.05)$. However, there was no significant difference between the performance of the two experimental groups on the writing posttest $(p=.212>0.05)$.

To explore the perceptions of the learners towards the efficacy of input enhancement and input flooding towards the improvement of their writing performance, five participants in each experimental group were interviewed.

The first question of the interview aimed to probe the participants' perceptions regarding their general viewpoint of using the enhanced and flooded materials in the study. The interviewees from the input enhancement group all held positive views towards the enhanced materials in general; however, one of the participants from the input flood group stated that she did not like the flooded content very much since the texts were full of simple present and continuous tenses.

The second interview question aimed to explore the problems that the participants had with the materials. Four of the participants in the input enhancement group were fully satisfied with the materials and stated that there were no problems. However, one of the interviewees in this group stated that the highlighted and italicized content was a bore to her eyes. As for the input flood group, only one of the interviewees stated that too many instances of the tenses seemed artificial in the texts.

The third interview question was concerned with the positive points that the learners associated with the enhanced and flooded materials. Four of the interviewees in the input enhancement group stated that they really liked the way the content was brought to their attention via enhanced materials and this assisted them in learning the grammar under instruction better. Similarly, all of the participants in the input flood group commented that the positive point for the flooded materials was that too many instances of the grammar helped them to produce the grammar in their writings more easily.

The fourth interview question was whether the participants found the enhanced and flooded materials useful. The interviewees in the input enhancement group thought that the content was useful and helped them improve their writing, as they had no difficulty remembering the structures when they were doing their writings. Likewise, the participants from the input flood group said that they found the materials very useful in terms of their contribution to their writing since mere repetition of the language points helped them learn and remember the points better.

The fifth question of the interview asked the participants whether they would like to receive similar materials for their future courses. Out of the five interviewees in the input enhancement group, all answered this question affirmatively. However, one of the learners from the input flooding group stated that she would like to see such materials in future courses but with fewer instances of the grammar under instruction.

\section{DISCUSSION}

The present study aimed at investigating the effects of input enhancement and input flooding of the present simple and continuous tenses on improving Iranian elementary EFL learners' writing performance. Moreover, the study sought to explore the perceptions of the learners towards the efficacy of input enhancement and input flooding 
towards the improvement of their writing performance. The results of statistical analyses indicated that both input enhancement and input flooding positively affected learners' writing performance. Moreover, there was no significant difference between the effects of input flooding and input enhancement on writing performance. The results of content analysis on interview questions revealed that the learners in both experimental groups held positive views towards the efficacy of input enhanced and input flooded materials towards improving their writings.

The results of the present study concerning the positive effect of input enhancement on writing performance are in line with those of a study by Fahim and Vaezi (2011) in which they found that enhanced input had a statistically significant impact on learning collocations. In a similar vein, the results of a study by Mayén (2013) revealed that the application of input enhancement was helpful to second language learners to learn and recall verbal morphology. Likewise, the results of this study are in line with those of a study by Birjandi, Alavi and Najafi (2015) in which they input enhancement had a significantly better effect on L2 learners' ability to learn English phrasal verbs than unenhanced input. However, the findings of the present study concerning the positive effect of input enhancement are incongruent with the results of Loewen and Inceoglu's (2016) study in which they came to the conclusion that visual IE did not contribute significantly to learning the Spanish past tense.

The results of the current study regarding the positive effect of input flooding on writing are in line with the findings of Rikhtegar and Gholami's (2015) study. The results of Rikhtegar and Gholami's (2015) investigation revealed that the group exposed to input flooded materials outperformed the other group which received conventional grammar instruction on the grammar posttest. This finding is; however, in contrast with Nemati and Motallebzadeh's (2013) study in which the scholars found that input flooding did not have a significant effect on the acquisition of the forms under instruction.

The findings of the present study concerning the lack of any significant difference between the effects of input enhancement and input flooding on writing performance are in line with the results of Afraz and Ebrahimi's (2014) in which they found that input enhancement and input flooding were both significantly effective on learning causative structures and no significant difference was found between the effects of the two modes of input on learning causative structures. Likewise, AsadiAmirabadi, Biria and Sedaghat's (2014) in their study showed that that the group exposed to a combination of input flood and input enhancement outperformed the other two classes which were exposed to either input enhanced or input flood materials and were not significantly different from each other on the posttest.

As for the contribution of both input enhancement and input flooding to improving writing, the results of this study can be explained in accordance with the noticing hypothesis. According to Noticing hypothesis (Schmidt, 1994), drawing L2 learners' attention to intended language forms can help learners to notice the gap between their present interlanguage and the target language. Schmidt's (1994) Noticing Hypothesis asserts that seeing L2 highlights in the written or spoken input to which L2 learners are exposed through reading is considered as a necessary and sufficient condition for 
turning input into the intake, which is necessary for learning to occur. Besides, as mentioned by Krashen (1985), the input should be comprehensible and L2 learners must be ready to acquire it. It seems that input enhanced and flooded content makes the input comprehensible enough, preparing L2 learners to understand it. The fact that noticing was a contributing factor towards writing can also be inferred from the participants' interview results in the present study. As the interviewees in the input enhancement group commented; they really liked the way the content was brought to their attention via enhanced materials. Likewise, the participants in the input flood group believed that the positive point for the flooded materials was in that too many instances of the grammar helped them a lot to produce the grammar needed in their writings more easily. Moreover, the findings of the statistical analyses concerning the positive contribution of both types of input towards writing performance were substantiated by the results of the interviews. As it was revealed in the interview results the interviewees from the input enhancement group all held positive views towards the enhanced materials. Similarly, the participants in the input flooding group also pointed to the usefulness of this type of input for improving their writing.

Based on the results of the study, two feasible methods for teaching present simple and continuous tenses in English are input flooding and input enhancement. Moreover, the findings of the present study further consolidate the important role of exposure to linguistic input and noticing in the learning of grammar and improving writing. The salient feature of input flooding is repeated exposure to linguistic input and the main characteristic of input enhancement is the noticing of input. As a result, the findings of the present study corroborate the role of exposure and noticing in learning grammar and its contribution to writing. Thus the findings of the current study pay contribution to the theory of noticing hypothesis proposed by Schmidt (1990).

\section{CONCLUSION}

In the Iranian ELT context not much attention is given to writing. Thus, it is of high importance to try to figure out what types of materials and/or activities may lead to improvement in the writing performance. Moreover, input has also been found to play critical role in the language acquisition process. Given the important role of input and the pivotal role of writing, the current study aimed at investigating the effects of input enhancement and input flooding on improving Iranian elementary EFL learners' writing performance. Additionally, the study sought to explore the perceptions of the learners about the efficacy of input enhancement and input flooding procedures. The results of ANOVA reveled that both input enhancement and input flooding positively affected learners' writing performance. However, no significant difference was found between the effects of input flooding and input enhancement on writing performance. The results of content analysis on interview questions confirmed the findings of the statistical analyses. The learners in both experimental groups held positive views towards the efficacy of input enhanced and input flooded materials towards improving their writings.

In the present study, the researcher did not have access to male learners. Thus a similar study can be carried out with male participants. Moreover, the participants of the current study were all at the elementary level. Therefore, future researchers are encouraged to 
replicate the current study with other proficiency levels. Additionally, in the present study, only the present simple and continuous tenses were enhanced and flooded. A similar study can employ other tenses appropriate for the elementary level.

The findings of the present study promise several implications. Firstly, the use of enhanced and flooded materials should be further emphasized in teaching grammar. Moreover, language teachers need to be well prepared to handle input flooded and input enhanced materials in their classroom which put further responsibility on the shoulder of teacher trainers and teacher education systems to equip teachers with the merits of these two types of input. In other words, teacher educators should expound upon the role of input flooding and input enhanced materials and the contribution of such materials to language learning in general and writing in particular in their teacher training courses. Materials developers need to incorporate input enhanced and flooded materials in their materials if the intention is further emphasis on these input types in language classrooms.

\section{REFERENCES}

Afraz, Sh., \& Ebrahimi, Sh. (2014). The comparative effect of input flooding vs. visual input enhancement on learning causative structures. International Journal of Educational Investigations, 13(4), 21-35.

Alipanahi, F. (2015). Feedback and writing performance of Iranian EFL learners. ELT Voices- International Journal for Teachers of English, 12(5), 60-72.

Al-Meni, A. M. O. (2008). An investigation of the effect of computer-assisted writing instruction on EFL Saudi learners' ability (Unpublished master thesis). King Saud University, Riyadh, KSU.

Anderson, J. R. (1982). Acquisition of cognitive skill. Psychological Review, 89(4), 369-40.

Anderson, J. R. (1983). The architecture of cognition. Cambridge, MA: Harvard University Press.

AsadiAmirabadi, Y., Biria. R., \& Sedaghat, A. (2014). Efficacy of input flood vs. input enhancement in the learning and long term retention of conditionals by intermediate Iranian EFL students. International Journal of Language Learning and Applied Linguistics World (IJLLALW), 7(3), 562-575.

Aslani, S. M., \& Heidari Tabrizi, H. (2015). Teaching grammar to Iranian EFL learners through blended learning using multimedia softwares. Journal of Applied Linguistics Language Research, 2(8), 76-87.

Auerbach, C. F., \& Silverstein, L. B. (2003). Qualitative data: An introduction to coding and analysis. New York, NY: New York University Press.

Azizifar, A., Babaei, M., Jamalinesari, A., \& Gowhary, H. (2015). The effect of grammatical consciousness raising task on Iranian EFL learners' reading comprehension. Procedia - Social and Behavioral Sciences, 192(3), 252-259. 
Baghban Ferdous, A. (2015). Investigating the effects of written output and input enhancement on EFL learners' grammatical development. Journal of Applied Linguistics and Language Research, 2(2), 138-156.

Birjandi, P., Alavi, S. M., \& Najafi, K. S. (2015). Effects of unenhanced, enhanced, and elaborated input on learning English phrasal verbs. International Journal of Research Studies in Language Learning, 4(1), 43-59.

DeKeyser, R., \& Sokalski, K. (1996). The differential role of comprehension and production practice. Language Learning, 46(7), 613-642.

Ellis, R. (1990). Instructed second language acquisition. Oxford: Blackwell.

Ellis, R. (1997). Second language acquisition research and language teaching. Oxford: Oxford University Press.

Fahim, M., \& Vaezi, R. (2011). Investigating the effect of visually-enhanced input on the acquisition of lexical collocations by Iranian intermediate EFL learners: A case of verb-noun lexical collocations. Journal of Language Teaching and Research, 2(3), 552560 .

Ghafoori, B., Dastgoshadeh, A., Aminpanah, A., \& Ziaei, Sh. (2016). The effect of call on Iranian EFL learners' grammar of writing. International Journal of Language Learning and Applied Linguistics World, (IJLLALW), 12(3), 14-23.

Jun, Z. (2008). A comprehensive review of studies on second language writing. $H K B U$ Papers in Applied Language Studies, 12, 89-123.

Ketabi, S., \& Torabi, R. (2013). Teaching academic writing in Iranian EFL classrooms: teacher-initiated comments or peer-provided feedback? Iranian Journal of Research in English Language Teaching (IJRELT), 1(2), 58-65.

Khodabakhshzadeh, H., \& Samadi, F. (2018). The effect of collaborative writing on Iranian EFL learners' task achievement in writing and their perception. International Journal of Applied Linguistics \& English Literature, 7(1),113-119.

Kol, S., \& Schcolnik, M. (2008). Asynchronous forums in EAP: Assessment issues. Language Learning \& Technology, 12(2), 49-70.

Krashen, S. (1985). The input hypothesis: Issues and implications. New York, NY: Longman.

Lai, Y. L. (2005). Teaching vocabulary learning strategies: Awareness, beliefs, and practices. A survey of Taiwanese EFL senior high school teachers (Unpublished master thesis). University of Essex, England.

Lai, Sh. (2015). EFL students' perceptions of corpus-tools as writing references. In F. Helm, L. Bradley, M. Guarda, \& S. Thouësny (Eds), Critical CALL - Proceedings of the 2015 EUROCALL Conference, Padova, Italy (pp. 336-341). Dublin: Researchpublishing.net.

Lightbown, P., \& Spada, N. (1990). Focus on form and corrective feedback in communicative language teaching: Effects on second language learning. Studies in Second Language Acquisition, 12(5), 429-448. 
Loewen, L., \& Inceoglu, S. (2016). The effectiveness of visual input enhancement on the noticing and L2 development of the Spanish past tense. Studies in Second Language Learning and Teaching (SSLLT), 6(1), 89-110.

Mahjoob, E. (2015). A comparison of the effectiveness of inductive vs. deductive instruction of grammar to EFL students. Journal of Language, Linguistics and Literature, 1(5), 164-169.

Mayen, R. S. (2013). Effects of input enhancement and visual prompts in children's 12 acquisition of Spanish verbal morphology. ELIA, 13(1), 83-111.

McCutchen, D. (2011). From novice to expert: Implications of language skills and writing-relevant knowledge for memory during the development of writing skill. Journal of Writing Research, 3(1), 51-68.

Melissourgoua, M., \& Frantzi, K. (2015). Testing writing in EFL exams: The learners' viewpoint as valuable feedback for improvement. Procedia - Social and Behavioral Sciences, 7(199), 30-37.

Nation, I. S. P. (1990). Teaching and learning vocabulary. Boston, Mass.: Heinle \& Heinle Publishers.

Nemati, F., \& Motallebzadeh, Kh. (2013). Input Flooding: A Factor to Improve Iranian Pre- Intermediate EFL Learners' Structural Accuracy. British Journal of Education, Society \& Behavioral Science, 3(4), 407-418.

Schmidt, R. (2001). Attention. In P. Robinson (Ed.), Cognition and second language instruction (pp. 3-32). Cambridge: Cambridge University Press. http://dx.doi.org/10.1017/CBO9781139524780.003

Nemati, F., \& Motallebzadeh, K. (2013). Input flooding: A factor to improve Iranian pre-intermediate EFL learners' structural accuracy. British Journal of Education, Society \& Behavioral Science, 3(4), 407-418.

Rikhtegar, O., \& Gholami, J. (2015). The effects of pre- versus post-presentation input flooding via reading on the young Iranian EFL learners' acquisition of simple past tense. English Language Teaching, 7(8), 80-88.

Schmidt, R. (1990). The role of consciousness in second language learning. Applied Linguistics, 11(2), 129-158.

Schmidt-Reinhart, B. (1994). The effects of topic familiarity on second language listening comprehension. Modern Language Journal, 78(1), 179-189.

Shahzadi, A., \& Janjua, F. (2016). Pakistani ESL student's attitude towards English language grammar: A case study of university of education Lahore. Journal of Literature, Languages and Linguistics, 20(1), 17-23.

Simard, D. (2002). La mise en évidencetextuelle: d'oùvenons-nous et oùallons-nous? The Canadian Modern Language Review, 59(2), 236-263.

Smith, M. S. (1993). Consciousness raising and the second language learner. In Applied Linguistics, 2(2), 36-48. 
Swan, M. (2009). Correspondence. ELT Journal, 63(3), 300-301.

Tahmouresi, N., Ahmadi, D., \& Gholami M. (2015). The effect of textual input enhancement on learning verbals in high-school EFL male students. International Journal of Educational Investigations, 2(8), 25-35.

Tarasova, F., Mukharlyamova, L., Ashrapova, A., Mukhametzyanova, L., Shayakhmetova, L., \& Ilyasova, L. (2016). Active approach in teaching grammar to bilingual EFL learners. Journal OF Current Research in Science (JCRS), 4(1), 94-99.

Thornbury, S. (1999). Lesson art and design. ELT Journal, 53(1), 4-11.

Thornbury, S. (2004). How to teach grammar. Longman, England.

Underwood, R. P. (2017). Challenges and change: Integrating grammar teaching with communicative work in senior high school EFL classes. SAGE Open, 3(1), 1-15.

VanPatten, B. (2004). Processing instruction: Theory, research, and commentary. Mahwah, NJ: Lawrence Erlbaum.

Vujic, J. (2015). Deconstructing English articles a construction grammar approach to teaching articles in English. The Journal of West University of Timisoara, 12(1), 67-81.

Vygotsky, L. (1987). The collected works of L. S. Vygotsky, Volume 1: Problems of general psychology. New York, NY: Plenum Press.

Widianingsih, N. K. L., \& Gulö, I. (2016). Grammatical difficulties encountered by second language learners of English. Proceedings of the Fourth International Seminar on English Language and Teaching, 2(1), 141-145.

Widdowson, H. G. (1990). Aspects of language teaching. Oxford: Oxford University Press.

Widodo, H. (2004). Kemampuan mahasiswa Bahasa Inggris dalam menganalisis kalimat bahasa Inggris. Fenomena, 3(2), 27-38.

Wigglesworth, G., \& Storch, N. (2009). Pairs versus individual writing: Effects on fluency, complexity, and accuracy. Language Testing, 26(3), 445-466.

Wong, W. (2004). Processing instruction in French: The roles of explicit information and structured input. In B. VanPatten (Ed.), Processing instruction: Theory, research, and commentary (pp. 187-205). Mahwah, NJ: Erlbaum.

Zarifi, A., \& Taghavi, A. (2016). The impact of cooperative learning on grammar learning among Iranian intermediate EFL learners. Theory and Practice in Language Studies, 6(7), 1429-1436.

Zhong-guo, Li., \& Min-yan, S. (2007). The relationship between traditional English grammar teaching and communicative language teaching. US-China Educational Review, 4(1). 62-65. 